\title{
OPTIMUM CONDITIONS FOR N-ACETYL GLUCOSAMINE PRODUCTION FROM TIGER SHRIMP (PENAEUS MONODON) SHELL BY SERRATIA MARCESCENS
}

\author{
YUNIWATY HALIM ${ }^{1}$, HARDOKO ${ }^{1,2}$, RATNA HANDAYANI ${ }^{1}$, VANIA LUCIDA ${ }^{1}$ \\ ${ }^{1}$ Department of Food Technology, Universitas Pelita Harapan, Jl.M.H. Thamrin Boulevard, Lippo Karawaci, Tangerang 15811, Indonesia. \\ ${ }^{2}$ Faculty of Fisheries and Marine Sciences, Universitas Brawijaya, Jl. Veteran No. 1 Malang, Indonesia. \\ Email: yuniwaty.halim@uph.edu and hardoko@ub.ac.id \\ Received: 06 August 2018, Revised and Accepted: 21 September 2018
}

ABSTRACT

Objective: The aim of this research was to determine the optimum condition for Serratia marcescens to produce optimum amount of N-acetyl glucosamine using chitin isolated from tiger shrimp (Penaeus monodon) shells.

Methods: This research was conducted using submerged fermentation method. The treatments used were various fermentation temperatures (20, 30 , and $\left.37^{\circ} \mathrm{C}\right)$, $\mathrm{pH}(6,7$, and 8$)$, and incubation period $(2,4,6$, and 8 days).

Results: Chitinolytic index of Serratia marcescens was $2.203 \pm 0.59$ after 2 days of incubation. Optimum temperature for N-acetyl glucosamine production using $S$. marcescens was at $30^{\circ} \mathrm{C}$. Optimum $\mathrm{pH}$ and incubation period for $\mathrm{N}$-acetyl glucosamine production were at pH 8 and 6 days of incubation period.

Conclusion: $S$. marcescens is able to ferment chitin from shrimp shell to produce N-acetyl glucosamine of $41,166.11 \pm 4,480.59$ mg/l at optimum fermentation condition.

Keywords: N-acetyl glucosamine, Fermentation, Serratia marcescens, Chitin, Tiger shrimp.

(C) 2018 The Authors. Published by Innovare Academic Sciences Pvt Ltd. This is an open access article under the CC BY license (http://creativecommons. org/licenses/by/4. 0/) DOI: http://dx.doi.org/10.22159/ajpcr.2019.v11i12.28956

\section{INTRODUCTION}

The production of shrimp waste from shrimp processing industries and restaurants has increased dramatically in recent years. In Indonesia, the amount of shrimp exported from Indonesia increased up to $8.5 \%$. However, the shrimp is usually exported after peeling, with head and shrimp shells are left as a waste. Moreover, the waste itself constitute about $70-80 \%$ of the landed catch [1]. Several methods have been used to reduce the waste of the crustacean, especially shrimp such as ocean dumping, incineration, or disposal to landfill sites. In recent years, techniques to utilize the biopolymer waste including shrimp have been developed. Shellfish wastes are mainly protein and chitin. The shrimp waste contains $8-10 \%$ chitin concentration, hence, increasing the development on how to separate this compound for better function [2].

Chitin is a polysaccharide which can be further processed into chitosan and glucosamine. Glucosamine is known to maintain strength, flexibility, and elasticity of tissues such as cartilage, mucous membranes, and synovial fluid which then used to treated symptoms of osteoarthritis and having properties of anti-inflammatory, antibacterial, and anticancer effects [3]. Previous research stated that the use of glucosamine combined with chondroitin sulfate is an effective treatment for osteoarthritis knee [4].

Glucosamine is also reported as one of the components in the supplement consumed by people who undergo warfarin therapy [5]. Glucosamine can be found naturally in human body mainly in cartilage and present in three forms which are D-glucosamine, N-acetyl glucosamine, and glucosamine hydrochloride. Glucosamine hydrochloride produced from chemical reaction of acid hydrolysis of chitin while D-glucosamine and $\mathrm{N}$-acetyl glucosamine are produced by the help of microorganisms through fermentation or DNA recombinants [6].

Chemical treatment is a popular method to produce glucosamine; however, a big concern came across in this method because concentrated acid waste is produced and exposed to the environment [7]. Furthermore, chemically produced glucosamine usually tastes bitter due to these residual substances [8]. Some researchers have developed fermentation process of glucosamine production using the crude enzyme of the chitinolytic bacteria such as Escherichia coli. Chitinase is an enzyme which catalyzes the degradation of chitin to its oligomers (chitooligosaccharides) and monomers (N-acetyl glucosamine) [9]. Due to its high cost to extract and produce its crude enzyme, fermentation process using its own bacteria rather than using the enzyme might be developed and there are still a few researches regarding the fermentation process and factors that influence the glucosamine produced.

In nature, bacteria produce several chitinases that can hydrolyze different form of chitin [10]. Serratia marcescens is one of the chitinolytic bacteria which can be used for producing glucosamine. S. marcescens itself can be found many in the soil and in the water [11]. The chitinase enzyme activity of Serratia spp. has been analyzed including its production and activity affected by several factors such as $\mathrm{pH}$ and temperature. Thus, this research was aimed to determine the optimum condition of $\mathrm{pH}$, temperature, and fermentation time for $S$. marcescens to produce optimum amount of $\mathrm{N}$-acetyl glucosamine.

\section{METHODS}

Preparation of stock culture and working culture

Stock culture of $S$. marcescens used in this research was obtained from Bandung Institute of Technology. The bacteria were then grown on slant nutrient agar. About $6 \mathrm{ml}$ of agar was poured into the tubes and then sterilized using autoclave for $20 \mathrm{~min}$ at $121^{\circ} \mathrm{C}$. After sterilization, tubes were transferred into the rack and placed with $20^{\circ}$ angle then let it cool to create a slant. One loop of stock culture of $S$. marcescens from the culture tube was taken and streaked into the slant agar. The bacteria were then incubated at $37^{\circ} \mathrm{C}$ for $24 \mathrm{~h}$. After $24 \mathrm{~h}$, the agar and bacteria were stored at $4^{\circ} \mathrm{C}$ in refrigerator. Working culture was then 
prepared by taking one loop of the bacteria from the nutrient agar and transferred it into tube filled with $10 \mathrm{ml}$ of nutrient broth [12]

\section{Bacterial cell counting}

Bacterial cell counting was performed to determine the number of bacteria should be added during the fermentation. The bacteria cell was counted using hemocytometer. $1 \mathbf{~ m l}$ of bacteria suspension in Nutrient Broth was taken and added with $1 \mathrm{ml}$ of methylene blue as a color indicator. The methylene blue was diluted in ratio 1:5. The suspension was then mixed vigorously until homogenized. Afterward, $0.1 \mathrm{ml}$ of the bacteria suspension was taken and put inside the hemocytometer [13]. Calculation of bacteria cells was done based on the following formula:

$$
\text { Colony count }\left(\frac{c f u}{m L}\right)=\text { average of cells in square } x 25 \text { square }
$$$$
x 10 \times 10^{3} x \text { dilution factor }(d f)
$$

\section{Preparation of isolated chitin}

Tiger shrimp (Penaeus monodon) shell used in this research was obtained from PT. Lola Mina located in Muara Baru, Jakarta, Indonesia. Approximately $40 \mathrm{~kg}$ of shrimp shell was cleaned thoroughly then sundried for 1-2 days. The shrimp shell powder was then further size reduced using dry blender and sieved using 35-mesh sieve shaker, resulting in a smooth shrimp shell powder [14]. Shrimp shell powder was then analyzed for its moisture content [15], ash content [15], and protein content using Bradford method [16]

Afterward, shrimp shell powder was then demineralized and deproteinated to obtain chitin. Shrimp shell powder was treated with $1 \mathrm{M} \mathrm{HCl}$ at $75^{\circ} \mathrm{C}$ for $2 \mathrm{~h}$ in the ratio of $1: 10(\mathrm{w} / \mathrm{v})$. Then, shrimp shell powder was rinsed with water to remove the acid and dried in the oven at $60^{\circ} \mathrm{C}$ for $24 \mathrm{~h}$. The dried, demineralized powder was then treated with $3.5 \% \mathrm{NaOH}$ with ratio $1: 10(\mathrm{w} / \mathrm{v})$ at $80^{\circ} \mathrm{C}$ for $2 \mathrm{~h}$. After $2 \mathrm{~h}$, the powder was then rinsed with water until the $\mathrm{pH}$ reached neutral and then dried in the oven at $60 \mathrm{oC}$ for $24 \mathrm{~h}$. The dried powder obtained was isolated chitin powder. The isolated chitin was then analyzed for its moisture content [15], yield [17], ash content [15], protein content [16], and degree of acetylation [18]. The determination of the degree of deacetylation of the isolated chitin produced was conducted by LIPI Physics Research Center. The degree of acetylation then was calculated using the following formula:

$$
\text { Degree of acetylation }(\%)=\frac{A 1655}{A 3450} \times 115
$$

A1655 and A3450 represented the spectrum bands used, respectively, which are at $1655 \mathrm{~cm}^{-1}$ that represent the absorbance of the carbonyl group present in $\mathrm{N}$-acetyl group and at $3450 \mathrm{~cm}^{-1}$ which represent the absorbance of $\mathrm{NH}_{2}$ group [19].

\section{Preparation of colloidal chitin}

It was made by mixing $100 \mathrm{~g}$ chitin powder with concentrated $\mathrm{HCl}$ with the ratio $(\mathrm{w} / \mathrm{v})$ of $1: 12$ and stirred for $1.5 \mathrm{~h}$ using magnetic stirrer until all the chitin powder had dissolved thoroughly. Afterward, about $500 \mathrm{ml}$ of cold ethanol was added into the mixture. The precipitate was then centrifuged at $8000 \mathrm{rpm}$ for $10 \mathrm{~min}$ and the solid was separated from its supernatant. Concentrated $\mathrm{NaOH}$ solution was added to the supernatant until the $\mathrm{pH}$ became neutral. Centrifugation at $8000 \mathrm{rpm}$ for $10 \mathrm{~min}$ was then performed repetitively to obtain solid part, which was the colloidal chitin [20]. Colloidal chitin was then used as a part of the media used in the fermentation.

\section{Determination of chitinolytic activity of $S$. marcescens}

The chitinolytic activity of $S$. marcescens was determined by measuring the clear zone produced after addition of Bromcresol purple for $0.1 \%$ into the selective media. The selective media were prepared according to Table 1.

A $6 \mathrm{~mm}$ paper disc was dipped into $S$. marcescens containing Nutrient
Broth and placed on the top of the selective media in the Petri dish. Afterward, plates were incubated at $37^{\circ} \mathrm{C}$ for 2 days and clear zone was measured at day 1 and day 2 . Furthermore, chitinolytic activity was expressed as chitinolytic index [21]. The formula of chitinolytic index is as follows:

Chitinolytic index $=\frac{\text { Diameter of clear zone }(\mathrm{mm})-\text { diameter of colony }(\mathrm{mm})}{\text { Diameter of colony }(\mathrm{mm})}$

Determination of optimum temperature for $\mathrm{N}$-acetyl glucosamine production

The fermentation conducted in this research was submerged fermentation. Fermentation media were prepared according to the formula shown in Table 2. The amount of bacteria inoculated into the media was based on the result from bacterial cell counting, i.e., $1 \mathrm{ml}$. The fermentation was then carried out at various temperatures, which are $20^{\circ} \mathrm{C}, 30^{\circ} \mathrm{C}$, and $37^{\circ} \mathrm{C}$ for 6 days. After 6 days, the samples were heated at water bath for $45 \mathrm{~min}$ at $70^{\circ} \mathrm{C}$ to kill the bacteria and the liquid part of the sample was taken by filtering using Buchner filter. The liquid part obtained was $\mathrm{N}$-acetyl glucosamine and it was further quantified using an Ultraviolet-Visible (UV-VIS) spectrophotometer (Hitachi U-2000) [22]. The experimental design used was completely randomized factorial design with one factor, i.e., temperature. There were three replications carried out in this experiment.

Determination of optimum $\mathrm{pH}$ and incubation period for $\mathrm{N}$-acetyl glucosamine production

The optimum temperature obtained from previous result was then used to determine the optimum $\mathrm{pH}$ and incubation period. The fermentation media were prepared according to Table 2 . However, the media were adjusted into various $\mathrm{pH}$ condition, i.e., $\mathrm{pH} \mathrm{6,} \mathrm{7,} \mathrm{and} 8$ by either adding $\mathrm{NaOH} 1 \mathrm{M}$ or $\mathrm{HCl} 1 \mathrm{M}$, and the fermentation was carried out with several incubation periods, i.e., for $2,4,6$, and 8 days. The $\mathrm{N}$-acetyl glucosamine then was obtained by heating the sample at $70^{\circ} \mathrm{C}$ for $45 \mathrm{~min}$ to stop the fermentation process then was filtered using Buchner filter. The liquid part was $\mathrm{N}$-acetyl glucosamine and analyzed using Ultraviolet-Visible (UV-VIS) spectrophotometer (Hitachi U-2000) [22]. The experimental design used was completely randomized factorial design with two factors, i.e., $\mathrm{pH}$ and incubation period. There were three replications carried out in this experiment.

\section{Quantification of N-acetyl glucosamine}

Before quantification, $\mathrm{N}$-acetyl glucosamine standard curve was prepared. $\mathrm{N}$-acetyl glucosamine standard was made into several concentrations which are 1000, 2000,3000, 4000, 5000, and $6000 \mathrm{ppm}$. The samples of different concentration were added with $0.8 \%$ ninhydrin and $\mathrm{pH}$ buffer 7 . Afterward, the samples were heated for $15 \mathrm{~min}$ at $95^{\circ} \mathrm{C}$. The samples were then measured for their absorbance using UV-VIS

Table 1: Formulation for making selective media [18]

\begin{tabular}{ll}
\hline Ingredient & Amount (g/L) \\
\hline $\mathrm{KH}_{2} \mathrm{PO}_{4}$ & 0.3 \\
$\mathrm{~K}_{2} \mathrm{HPO}_{4}$ & 0.7 \\
$\mathrm{MgSO}_{4} \cdot 7 \mathrm{H}_{2} \mathrm{O}$ & 0.5 \\
Colloidal chitin & 5.0 \\
Nutrient agar & 20.0 \\
\hline
\end{tabular}

Table 2. Formula for making fermentation media [22]

\begin{tabular}{ll}
\hline Ingredient & Amount (w/v) \\
\hline Chitin & $2 \%$ \\
$\mathrm{KH}_{2} \mathrm{PO}_{4} \cdot 3 \mathrm{H}_{2} \mathrm{O}$ & $0.1 \%$ \\
$\mathrm{MgSO}_{4} \cdot 7 \mathrm{H}_{2} \mathrm{O}$ & $0.05 \%$ \\
Nitrogen source & $0.1 \%$ \\
Glucose & $2 \%$ \\
Aquadest & Until $50 \mathrm{ml}$ \\
\hline
\end{tabular}


spectrophotometer at $324 \mathrm{~nm}$. Based on the absorbance data obtained, standard curve was then prepared.

To measure the concentration of $\mathrm{N}$-acetyl glucosamine obtained after the fermentation. The samples were diluted in the ratio of $1: 5(\mathrm{v} / \mathrm{v})$. From the diluted sample, $4 \mathrm{ml}$ was taken then added with $0.5 \mathrm{ml}$ of $0.8 \%$ ninhydrin and $0.5 \mathrm{ml}$ of $\mathrm{pH}$ buffer 7 to control the $\mathrm{pH}$ at neutral condition. The mixture was then homogenized using vortex and the samples were then heated for $15 \mathrm{~min}$ at $95^{\circ} \mathrm{C}$. The samples were measured for their absorbance at $324 \mathrm{~nm}$. The quantity of the $\mathrm{N}$-acetyl glucosamine in the samples was calculated using equation formed from the standard curve [22]

\section{RESULTS AND DISCUSSION}

\section{Analysis of shrimp shell powder}

There were several analyses performed to determine the characteristics of shrimp shell powder obtained from demineralization and deproteinization process. Results of analyses can be observed in Table 3.

The moisture content of the shrimp shell powder was determined as it affects the shelf life of the powder and yield of the chitin produced. Moisture content of the shrimp shell powder obtained is $8.55 \pm 0.35 \%$. This result is slightly lower compared to moisture content of shrimp shell as stated in previous research, i.e., about $12.3 \pm 0.1 \%$ [23].

The initial ash content was important to see the completion of demineralization process of chitin. From Table 3, the ash content of the shrimp shell powder obtained is $40.76 \pm 0.54 \%$ which is higher than the previous researches done. Previous researches reported that the ash content of the shrimp shell is $26.6 \%, 27.09 \%$, and $26.45 \%$, respectively [23-25]. The different amount in the ash content can be affected by the feed of the shrimp itself and the environment of the shrimp.

The last property analyzed is protein content of the shrimp shell. The amount of initial protein content was needed to check the completion of deproteinization in the isolation of chitin. The protein content obtained from the analysis is $33.71 \pm 0.10 \%$. The result of the protein content analysis has similar value to a previous research, i.e. about $32.5 \pm 0.1 \%[23]$

\section{Analysis of isolated chitin}

Isolated chitin obtained from the shrimp shell powder was analyzed to see the quality of the chitin produced. The results can be shown in Table 4.

The moisture content of the isolated chitin produced is $5.29 \pm 0.11 \%$. The result of moisture content of isolated chitin produced is only slightly different from result of a previous research, which was about $6.89 \%$ [17]. Lesser moisture content is favorable as moisture content might increase the ability of chitin to bind with water which can reduce the shelf life if produced commercially.

Ash content of isolated chitin was measured to determine completion of the demineralization process. Demineralization process is one of the most important steps in chitin purification [26]. Ash content of the isolated chitin in this research is $0.67 \pm 0.18 \%$. Compared to a previous research, which is $7.8 \%$ [27], the isolated chitin produced has much less amount of ash content after demineralization process. The process of demineralization in another research was done by heating at $60^{\circ} \mathrm{C}$ for $30 \mathrm{~min}$ [27], while in this research, the demineralization process was done at $75^{\circ} \mathrm{C}$ for $2 \mathrm{~h}$. Higher heating temperature at longer time might help the demineralization process to run faster. Thus, the isolated chitin in this research has less amount of ash.

Other than demineralization, isolated chitin produced also gone through deproteinization process. It is because chitin is naturally linked to proteins by glycosidic bonds; therefore, it is required to perform deproteinization to obtain chitin [28]. It was also stated that deproteinization of shrimp shell is a crucial step in chitin production [29]. The protein content of the isolated chitin is $1.93 \pm 0.01 \%$. A previous research performed the deproteinization process using $2 \mathrm{~N} \mathrm{NaOH}$ while heated at $50^{\circ} \mathrm{C}$ for $4 \mathrm{~h}$ [28]. The concentration of $\mathrm{NaOH}$ used is higher than what used in this research which is $3.5 \% \mathrm{NaOH}$ and even the temperature for heating is lower, the process was done longer so that more protein was extracted.

Yield of the chitin isolated from the shrimp shell is $13.98 \pm 0.29 \%$. This value is lesser than other result stated in the previous research which is $20-27 \%$ [29]. However, yield of chitin obtained in this research is slightly higher than another research, which stated that shrimp waste usually contains about 8-10\% chitin [30].

Furthermore, one of the major concerns in chitin production that determines the quality of the final product was the degree of acetylation [31]. The degree of acetylation can be used to differentiate between chitin and chitosan. Chitin has degree of acetylation $>50 \%$ and insoluble, whereas chitosan has less value and soluble [32]. The degree of acetylation of the isolated chitin obtained in this research is $92.2 \%$, which shows that the compound obtained from deproteinization and demineralization process was indeed chitin, not chitosan. The result is also in accordance to the previous research which stated that the degree of acetylation of the chitin produced was 95\% [33].

\section{Bacteria cell counting}

The bacteria count of $S$. marcescens reaches the value of $6.8 \times 10^{7} \mathrm{CFU} / \mathrm{ml}$. The bacteria were counted at the early stationary stage of $S$. marcescens which was after $50 \mathrm{~h}$ of incubation [34]. Early stationary stage was the stage of the bacteria to start producing chitinase enzyme [35]. The fermentation process started as soon as the bacterial counts reached $10^{6}-10^{7} \mathrm{CFU} / \mathrm{ml}$ [36]. As from the result of counting, the cell bacteria per $\mathrm{ml}$ are $6.8 \times 10^{7} \mathrm{CFU} / \mathrm{ml}$, the amount of the bacteria suspension added to the fermentation media is $1 \mathrm{ml}$.

\section{Chitinolytic index}

The chitinolytic index was determined to ensure that Serratia marcescens used in this research possess the chitinolytic activity. Chitinolytic index was observed for 2 days, and the result of can be shown in Table 5.

The highest chitinolytic index of the bacteria was shown at 2 days of incubation which is $2.203 \pm 0.59$. This result also confirms the ability of Serratia marcescens to produce chitinase.

Table 3: Characteristics of shrimp shell powder

\begin{tabular}{ll}
\hline Parameter & Amount (\%) \\
\hline Moisture content & $8.55 \pm 0.35^{*}$ \\
Ash content & $40.76 \pm 0.54^{*}$ \\
Protein content & $33.71 \pm 0.10^{*}$ \\
\hline
\end{tabular}

*The analyses were done in three replications

Table 4: Characteristics of chitin powder

\begin{tabular}{ll}
\hline Parameter & Amount (\%) \\
\hline Moisture content & $5.29 \pm 0.18^{*}$ \\
Ash content & $0.67 \pm 0.18^{*}$ \\
Protein content & $1.93 \pm 0.01^{*}$ \\
Yield & $13.98 \pm 0.29^{*}$ \\
Degree of acetylation & 92.2 \\
\hline
\end{tabular}

*The analyses were done in three replications

Table 5: Chitinolytic index of Serratia marcescens

\begin{tabular}{ll}
\hline Day & Chitinolytic index \\
\hline 1 & $0.967 \pm 0.25^{*}$ \\
2 & $2.203 \pm 0.59^{*}$ \\
\hline *The analyses were done in three replications
\end{tabular}


Effect of temperature on $\mathrm{N}$-acetyl glucosamine production

The amount of $\mathrm{N}$-acetyl glucosamine produced by the fermentation which done for 6 days at 3 different temperatures which are $20^{\circ} \mathrm{C}$, $30^{\circ} \mathrm{C}$, and $37^{\circ} \mathrm{C}$. Incubation period of 6 days was chosen because the time needed for the Serratia marcescens to produce optimum amount of chitinase was after $144 \mathrm{~h}$ or 6 days of incubation [9]. From the statistical analysis, different temperatures gave significant effect on the production of $\mathrm{N}$-acetyl glucosamine $(\mathrm{p}<0.05)$. The concentration of $\mathrm{N}$-acetyl glucosamine produced in each temperature is shown in Fig. 1.

The highest amount of glucosamine produced was at $30^{\circ} \mathrm{C}$, i.e., $29,188.33 \pm 1,169.17 \mathrm{mg} / \mathrm{l}$. This result is in accordance with the previous research which stated that the optimum temperature for the chitinase enzyme to produce maximum amount of glucosamine was at $30^{\circ} \mathrm{C}$ [35]. This result is also supported by a previous research which stated that $S$. marcescens QMB1466 has the optimum temperature of $30^{\circ} \mathrm{C}$ to produce chitinase [37]. S. marcescens can live in wide range of temperature and it is proven that the $\mathrm{N}$-acetyl glucosamine can still be produced at incubation temperature of $20^{\circ} \mathrm{C}$ and $37^{\circ} \mathrm{C}$ [38]. The second highest concentration of $\mathrm{N}$-acetyl glucosamine produced was at $37^{\circ} \mathrm{C}$, i.e., about $19,305.01 \pm 2770.52 \mathrm{mg} / \mathrm{l}$. At $20^{\circ} \mathrm{C}$, S. marcescens produced the least amount of $\mathrm{N}$-acetyl glucosamine, i.e. about $14,377.22 \pm 1525.46 \mathrm{mg} / \mathrm{l}$.

Effect of $\mathrm{pH}$ and incubation period on $\mathrm{N}$-acetyl glucosamine production

The optimum temperature obtained from the previous stage of research, i.e., $30^{\circ} \mathrm{C}$ was then used to determine the optimum $\mathrm{pH}$ and incubation period to produce $\mathrm{N}$-acetyl glucosamine. The $\mathrm{pH}$ range of 6,7 , and 8 at four different incubation periods of 2, 4, 6, and 8 days was used. Statistical analyses show that there was a significant effect of both $\mathrm{pH}$ and incubation period on $\mathrm{N}$-acetyl glucosamine production $(\mathrm{p}<0.05)$. The interaction between the effect of $\mathrm{pH}$ and fermentation period to the amount of $\mathrm{N}$-acetyl glucosamine produced can be observed in Fig. 2 .

Statistical analysis result (Fig. 2) shows that the combination of $\mathrm{pH} 6$ and $\mathrm{pH} 7$ for 2 days of incubation period has no significant difference, in terms of $\mathrm{N}$-acetyl glucosamine produced, with incubation at $\mathrm{pH} 8$ for 2 days and $\mathrm{pH} 6$ for 4 days.

Moreover, the fermentation at $\mathrm{pH} 8$ for 6 days and at $\mathrm{pH} 8$ for 8 days gives no significant difference in $\mathrm{N}$-acetyl glucosamine production, at

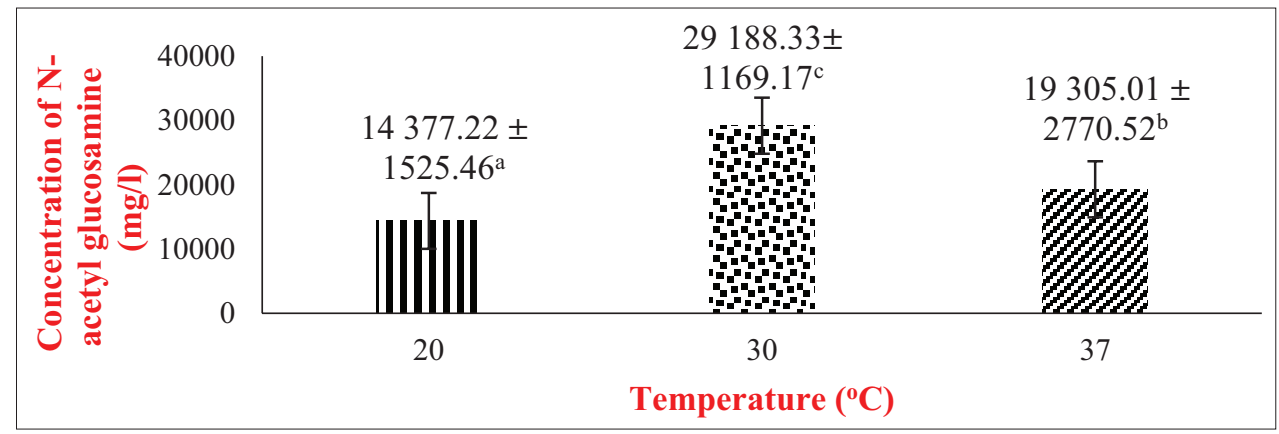

Fig. 1: Effect of temperature on production of $\mathrm{N}$-acetyl glucosamine. The different notations indicate a significant difference $(\mathrm{p}<0.05)$

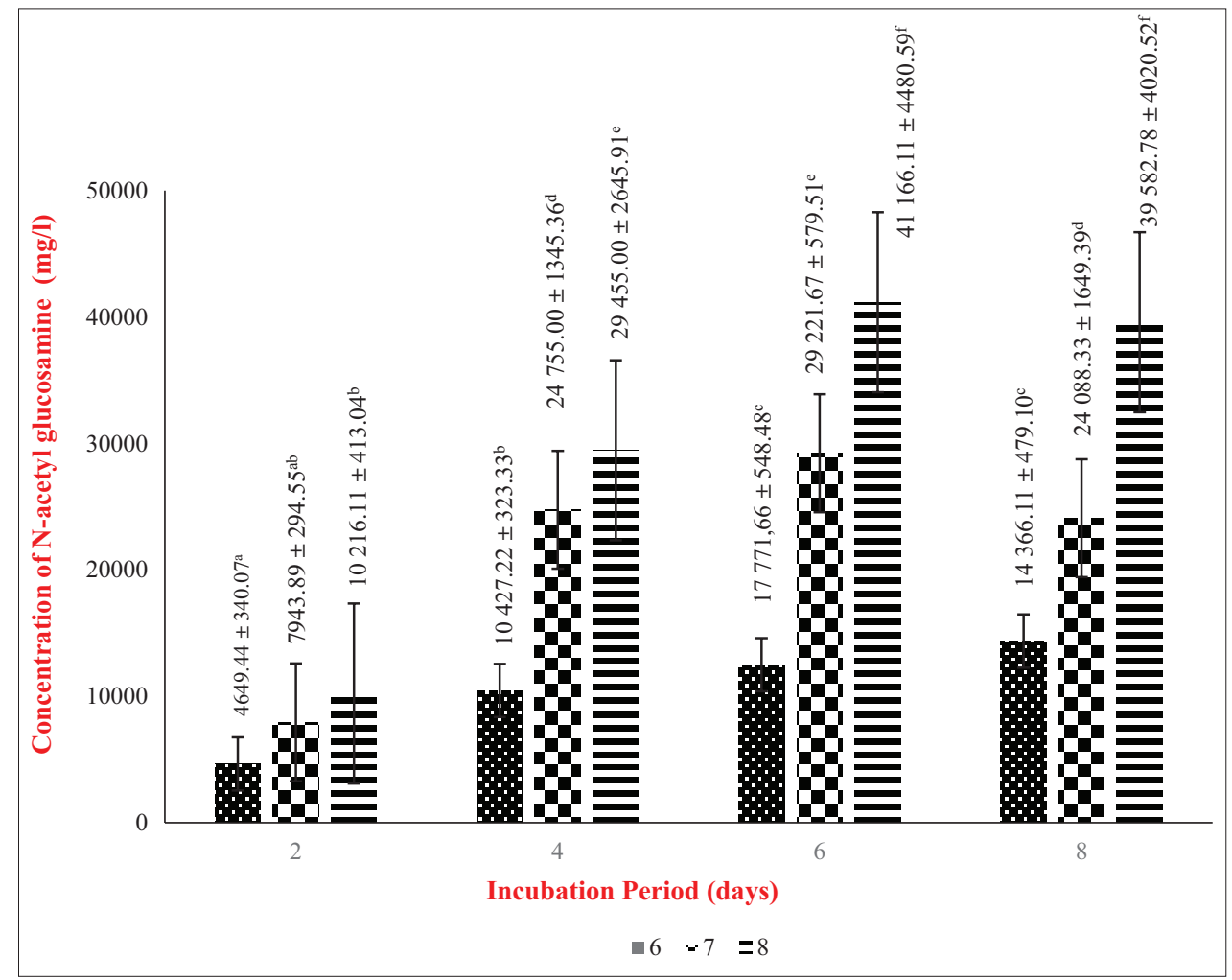

Fig. 2: Effect of $\mathrm{pH}$ and incubation period on production of $\mathrm{N}$-acetyl glucosamine. The different notations indicate a significant difference $(\mathrm{p}<0.05)$ 
which, both conditions gave the highest amount of $\mathrm{N}$-acetyl glucosamine produced, i.e., 41,166.11 $\pm 4480.59 \mathrm{mg} / \mathrm{l}$ and $39,582.78 \pm 4020.52 \mathrm{mg} / \mathrm{l}$, respectively. However, fermentation period of 6 days is considered more efficient; therefore, fermentation at $\mathrm{pH} 8$ for 6 days is considered as the optimum condition for $\mathrm{N}$-acetyl glucosamine production by $S$. marcescens. The optimum incubation period for optimum chitinase production by Serratia marcescens was after 6 days of incubation [35], which in accordance to the result from this research. This result is also supported by a previous research which stated that the optimum activity and the optimum amount of chitinase enzyme produced by S. marcescens were produced at $\mathrm{pH} 7.9$ [39].

The highestamount of $\mathrm{N}$-acetyl glucosamine obtained from fermentation by $S$. marcescens in this research, i.e., $41,166.11 \pm 4,480.59 \mathrm{mg} / \mathrm{l}$, is lower compared to fermentation by E. coli, which was $110,000 \mathrm{mg} / \mathrm{l}$ [7]. The difference of the amount of glucosamine produced is because in a previous research, the bacteria used were metabolically engineered E. coli. Therefore, they can produce optimum amount of glucosamine.

Furthermore, in the optimum conditions of fermentation ( $\mathrm{pH}$ media 8 , temperature $30^{\circ} \mathrm{C}, 6$ days of incubation), the yield of $\mathrm{N}$-acetyl glucosamine obtained was about $66.64 \pm 7.02 \%$ in dry basis from the initial chitin produced from P. monodon shrimp shells. This yield is comparable to $\mathrm{N}$-acetyl glucosamine yield obtained from chemical hydrolysis, with the highest yield reported was about $70 \%$ [40] and higher compared to $\mathrm{N}$-acetyl glucosamine yield obtained from fermentation using Bacillus licheniformis, which was about 41\% [41].

\section{CONCLUSION}

$\mathrm{N}$-acetyl glucosamine could be produced by fermentation process using $S$. marcescens with submerged fermentation method. Temperature, $\mathrm{pH}$, and incubation period have effect on the production of glucosamine. The optimum condition of the fermentation was at temperature of $30^{\circ} \mathrm{C}$ and $\mathrm{pH} 8$ for 6 days with the amount of $\mathrm{N}$-acetyl glucosamine produced was about $41166.11 \pm 4480.59 \mathrm{mg} / \mathrm{l}$.

\section{ACKNOWLEDGMENT}

The authors would like to thank Center of Research and Community Development, Universitas Pelita Harapan, Indonesia, for financially supporting this research through Project no: 258/LPPM-UPH/ VII/2017, and Laboratory of Microbiology and Laboratory of Quality Control at Universitas Pelita Harapan, Indonesia, for providing the necessary facilities.

\section{AUTHORS' CONTRIBUTION}

Research concept and experimental design: Hardoko. Data collection: Vania Lucida. Analysis and interpretation of data: Vania Lucida, Yuniwaty Halim, Hardoko, and Ratna Handayani. Manuscript preparation: Vania Lucida and Yuniwaty Halim. Critical input and revision of the manuscript: Hardoko. Overall, all authors have contributed equally based on their area of expertise.

\section{CONFLICTS OF INTEREST}

The authors declare that they have no conflicts of interest.

\section{REFERENCES}

1. Ramakrishnan MS, Brooks VV. Fish processing wastes as a potential source of proteins, amino acids and oils: A critical review. J Microb Biochem Technol 2013;5:107-29.

2. Islam M, Masum SM, Rahman MM, Shaikh AA. Preparation of glucosamine hydrochloride from indigenous shrimp processing waste. Bangladesh J Sci Ind Res 2011;46:375-8.

3. Bunaramrueang P, Attasat S. Optimum conditions for preparation of glucosamine hydrochloride and glucosamine sulfate from shrimp-shell chitin. Int J Appl Sci Technol 2016;6:24-9.

4. Mirunalini R, Chandrasekaran M, Manimekalai K. Efficacy of chondroitin sulfate with glucosamine versus diacerein in grade II and III osteoarthritis knee: A randomized comparative study. Asian J Pharm
Clin Res 2015;8:244-6.

5. Djunaedi M, Sulaiman SA. The pharmacist's assessment on patients who consume supplements and herbal while undergoing warfarin therapy. Asian J Pharm Clin Res 2018;11:49-54.

6. Mojarrad JS, Mahboob N, Valizadeh H, Ansarin M, Bourbour S. Preparation of glucosamine from exoskeleton of shrimp and predicting production yield by response surface methodology. J Agric Food Chem 2007;55:246-50.

7. Sitanggang AB, Sophia L, Wu HS. Aspects of glucosamine production using microorganisms. Food Res Int 2012;19:393-404.

8. Chen JK, Shen CR, Liu CL. N-acetylglucosamine: production and applications. Mar Drugs 2010;8:2493-516.

9. Thirumugan D, Sankari D, Vijayakumar, R. Screening of chitinase production and antifungal activity of Streptomyces sp. ACT 7 from East Coast region, South India. Int J Pharm Pharm Sci 2015;7:38-41

10. Krithika S, Chellaram C. Isolation, screening and characterization of chitinase producing bacteria from marine wastes. Int J Pharm Pharm Sci 2016;8:34-6.

11. Hejazi A, Falniker FR. Serratia marcescens. J Med Microbiol 1997;46:903-12.

12. Haedar N, Natsir FH, Aryanti W. Production and characterization of chitinase enzyme from chitinolytic bacteria obtained from shells Anadara granosa). Jurnal Alam dan Lingkungan. J of Nat and Envir 2017;8:19-28.

13. Dubey RC, Maheshwari DK. Practical Microbiology. New Delhi, India: S. Chand and Company Pvt. Ltd.; 2012.

14. Arif AR, Ischaidar HN, Dali S. Isolasi kitin dari limbah udang putih (Penaeus merguiensis) secara enzimatis. In: Proceedings of Seminar Nasional Kimia Peran Sains dan Teknologi dalam Mendukung Ketahanan Pangan dan Energi Nasional. Makassar, Indonesia: Publisher Hasanuddin University; 2013. p. 10-6.

15. AOAC. Official Methods of Analysis. USA (Maryland): Association of Official Analytical Chemists; 2005.

16. Bradford MM. A rapid and sensitive method for the quantitation of microgram quantities of protein utilizing the principle of protein-dye binding. Anal Biochem 1976;72:248-54.

17. Dompeipen EJ, Kaimudin M, Dewa RP. Isolation of chitin and chitosan from shrimp shells waste. Majalah Biam 2016;12:32-9.

18. Czechowska-Biskup R, Jarosinska D, Rokita B, Ulanski P, Rosiak JM. Determination of degree of deacetylation of chitosan-comparison methods. Prog Chem Appl 2012;17:5-20.

19. Lago MA, de Quirós AR, Sendón R, Sanches-Silva A, Costa HS, Sánchez-Machado DI, et al. Compilation of analytical methods to characterize and determine chitosan, and main applications of the polymer in food active packaging. CyTA J Food 2011;9:319-28.

20. Setia IN. Chinolytic assay and identification of bacteria isolated from shrimp waste based on 16S rDNA sequences. Ad Microbiol 2015;5:541-8

21. Suryadi Y, Priyano TP, Samudra M, Susilowati DN, Lawati N, Kustaman E. Partial purification and characterization of chitinase from entomopathogenic fungus Beauveria bassiana isolate BB200109. J Agro Biogen 2013;9:77-84.

22. Saskiawan I, Handayani R. Production of N-acetyl-D-glucosamine by submerged fermentation from chitin. Berita Biol 2011;10:292-7.

23. Ravichandran S, Rameshkumar G, Prince AR. Biochemical composition of shell and flesh of the Indian white shrimp Penaeus indicus (H. Milne Edwards 1837). Am-Eurasian J Sci Res 2009;4:191-4.

24. Sanusi M. Transformation of chitin from industrial waste isolation of frozen shrimps into chitosan. J Kimia FMIPA 2004;5:28-32.

25. Tanasale MF, Killay A, Laratmase MS. Kitosan dari limbah kulit kepiting rajungan (Portunus sanginolentus L.) sebagai adsorben zat warna biru metilena. J Nat Indo 2012;14:165-71.

26. Das S, Ganesh EA. Extraction of chitin from trash crabs (Podophthalmus vigil) by an eccentric method. Curr Res J Biol Sci 2010;2:72-5.

27. Dompeipen EJ. Isolasi dan identifikasi kitin dan kitosan dari kulit udang windu (Penaeus monodon) dengan spektroskopi inframerah. Majalah Biam 2017;13:31-41.

28. Díaz-Rojas EI, Argüelles-Monal WM, Higuera-Ciapara I, Hernández J, Lizardi-Mendoza J, Goycoolea FM. Determination of chitin and protein contents during the isolation of chitin from shrimp waste. Macromol Biosci 2006;6:340-7.

29. Lertsutthiwong P, How NC, Chandrkrachang S, Stevens WF. Effect of chemical treatment on the characteristics of shrimp chitosan. J Metals Mater Miner 2002;12:11-8.

30. Armenta RE, Guerrero-Legarreta I. Amino acid profile and enhancement of the enzymatic hydrolysis of fermented shrimp carotenoproteins. Food Chem 2009;112:310-5. 
31. Arbia W, Arbia L, Adour L, Amrane A. Chitin recovery using biological methods. Food Technol 2013;51:12-25.

32. Kasaai MR. Various methods for determination of the degree of $\mathrm{N}$-acetylation of chitin and chitosan: A review. J Agric Food Chem 2009;57:1667-76.

33. Percot A, Christophe V, Domard A. Optimization of chitin extraction from shrimp shells. Biomacromolecules 2003;4:12-8.

34. Hapsari F. Pemanfaatan Tepung Cangkang Udang Yang Dihidrolisis Enzim Kasar Kitinase Dalam Pakan Benih Ikan Patin (Pangasionodon hypopthalmus). Bogor, Indonesia: Master Thesis, Bogor Agricultural University; 2013.

35. Lamine BM, Lamine BM, Bouziane A. Optimisation of the chitinase production by Serratia marcescens DSM 30121T and biological control of locusts. J Biotechnol Biomater 2012;2:133.

36. Priest FG, Campbell I. Brewing Microbiology. USA: Springer; 2002.
37. Roberts RL, Cabib E. Serratia marcescens chitinase: One step purification and use for the determination of chitin. Anal Biochem 1982;127:402-12.

38. Brzezinska MS, Jankiewicz U, Burkowska A, Walczak M. Chitinolytic microorganisms and their possible application in environmental protection. Curr Microbiol 2013;68:71-81.

39. Zarei M, Saeed A, Zolgharnein H, Safahieh A, Ghoroghi A, Motallebi A, et al. Serratia marcescens B4A chitinase product optimization using Taguchi approach. Iran J Biotechnol 2010;8:52-63.

40. Ryosuke K, Yoshiharu M, Kazuaki K, Kazuo S. Production of naturaltype N-acetyl-D-glucosamine. JP Patent 2002;8:1696.

41. Pichyangkura R, Kudan S, Kuttiyawang K, Sukwattanasinitt M, Aiba S. Quantitative production of 2-acetoamodo-2-d-glucose from crystalline chitin by bacterial chitinase. Carbohydr Res 2002;337:557-9. 